\title{
Tabernaemontana catharinensis A. DC. Seedling Emergence and Growth in Different Substrates
}

\author{
Marcelo Vielmo Afonso ${ }^{1}$ (D) 0000-0003-3866-6492 \\ Juçara Terezinha Paranhos² (D) 0000-0002-0201-134X \\ Luciane Almeri Tabaldi ${ }^{2}$ (D) 0000-0002-3644-2543 \\ Hilda Hildebrand Soriani ${ }^{3}$ (D) 0000-0002-2563-7951 \\ Cleber Witt Saldanha ${ }^{4}$ (D) 0000-0001-6147-6027
}

\begin{abstract}
This work aimed to evaluate the influence of the substrate composition on the emergence, vigor, and growth of Tabernaemontana catharinensis seedlings in a greenhouse. Seeds were placed to germinate by testing the following substrates: pure Mecplant and combined with fine texture vermiculite (V) or charcoal rice husk (CRH) in different proportions. Variables of emergence percentage, emergence speed index, height, collection diameter, root length, leaf area, dry mass (shoot, root, and total), Dickson quality index, and photosynthetic pigment contents were evaluated. Germinated plants on pure Mecplant substrate presented lower emergence values and morphophysiological parameters. This commercial substrate associated with vermiculite at 1:1 and 1:3 proportions provided higher seed vigor and higher seedling growth, proving to be more adequate for the seedling formation of the species. The formulated substrates did not show a significant influence on the photosynthetic pigment contents.
\end{abstract}

Keywords: cobrina, native plant, seed germination, biomass, seedling production.

\section{INTRODUCTION AND OBJECTIVES}

In the last decade the forestry sector has been highlighting the search for native species with potential for use in reforestation programs, urban afforestation and reconstitution of areas for plant preservation (Basso et al., 2011). However, unlike commercial plants, there is a large gap regarding knowledge about the germination potential, growth and development of seedlings of native tree species in relation to different biotic and/or abiotic factors influencing them (Afonso et al., 2012).

The Tabernaemontana catharinensis A. DC. (Apocynaceae) species, popularly known as cobrina or jasmim catavento, is a native tree to Brazil, a pioneer dispersed in several forest formations (Lorenzi, 2009), and is recommended for reforesting degraded areas and for mixed plantations destined to recover native forest. In addition, it is rich in phytochemical compounds (Bélo et al., 2009), having bioinsecticidal capacity
(Corrêa \& Vieira, 2001) and antioxidant properties (Piana et al., 2014). Because of its importance, its propagation becomes critical to large-scale production. However, studies related to the seminal propagation of the species are scarce.

Therefore, searching for suitable techniques for producing and maintaining seedlings with desirable morphophysiological characteristics involves studying the seed germination processes and vegetative growth of the young plant, and several phytotechnical indicators can be used for this purpose (Erismann et al. 2006). Among the many factors affecting seedling production, substrate composition may not only interfere with seed germination but also with seedling support and development, such as the higher efficiency of the photosynthetic apparatus (Wendling et al., 2007).

However, difficulties regarding the best substrate formulation lead to studying alternative compositions, since hardly a single material would be able to meet all the requirements of the species to be propagated. For this reason, materials that

\footnotetext{
${ }^{1}$ Instituto Federal de Educação, Ciência e Tecnologia Farroupilha (IFFAR), Panambi, RS, Brasil

${ }^{2}$ Universidade Federal de Santa Maria (UFSM), Santa Maria, RS, Brasil

${ }^{3}$ Universidade Federal de Santa Maria (UFSM), Frederico Westphalen, RS, Brasil

${ }^{4}$ Centro de Pesquisa em Florestas, Santa Maria, RS, Brasil
} 
improve physical and chemical characteristics are essential (Mesquita et al., 2012). This effect quantitatively reflects the biomass production and thus the initial seedling growth and the seedling quality produced.

Thus, this work aimed to evaluate the influence of the composition of substrates on the emergence, vigor, and growth of $T$. catharinensis seedlings.

\section{MATERIALS AND METHODS}

This work was carried out in a greenhouse, located at

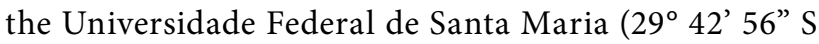
and $53^{\circ} 43^{\prime} 12^{\prime \prime} \mathrm{W}$ ), Santa Maria, RS, Brazil. Cobrina fruits were collected in May 2015 from the lateral medial third of the crown from five matrices with $4.0 \mathrm{~m}$ height, located in a plant remnant in the northwest region of Rio Grande do Sul. The seeds were removed from the fruits and subjected to the natural drying process in the shade for five days. After this period, they were placed to germinate in styrofoam trays with 72 individual cells with a capacity of $121 \mathrm{~cm}^{3}$ of substrate, at a depth of $1.0 \mathrm{~cm}$ and kept in a greenhouse with a temperature of $25 \pm 3{ }^{\circ} \mathrm{C}$, relative humidity of $80 \%$, light intensity of $1,081 \mu \mathrm{mol} \mathrm{m}^{-2} \mathrm{~s}^{-1}$, and daily irrigation.

Treatments were constituted by different substrate combinations (v:v) of Mecplant ${ }^{\circ}$ (commercial substratum based on pinus bark), fine texture vermiculite $(\mathrm{V})$, and charcoal rice husk (CRH), in which: T1) $100 \%$ Mecplant ${ }^{\circ}$; T2) $75 \%$ Mecplant $^{\circ}+25 \%$ V; T3) 50\% Mecplant $^{\oplus}+50 \%$ V; T4) $25 \%$ Mecplant $^{\oplus}+75 \%$ V; T5) 75\% Mecplant $+25 \%$ CRH; T6) $50 \%$ Mecplant $^{\oplus}+50 \%$ CRH; T7) 25\% Mecplant ${ }^{\oplus}+75 \%$ CRH. Physical and chemical characteristics (Table 1) of the substrates were obtained at the Laboratory of Analysis of Substrates for Plants (LASPP) from the Fundação Estadual de Pesquisa Agropecuária (FEPAGRO), headquartered in Porto Alegre, RS, Brazil. All treatments received $8.0 \mathrm{~g} \mathrm{~L}^{-1}$ of Osmocote ${ }^{\bullet}$ (NPK fertilizer, formulation 15-9-12), with a release period of five to six months, as recommended by the manufacturer.

The experiment was conducted in a completely randomized design with four replicates of 18 seeds, totaling 72 seeds per treatment. The evaluations were performed every three days, until the emergence was stabilized in each treatment. The evaluated characteristics were emergence percentage (E\%), with a seedling being considered emerged when the cotyledons were totally free above the ground (Labouriau \& Valadares, 1976), and the emergence speed index (ESI) according to the formula proposed by Maguire (1962).

After emergence stabilization, seedlings were transferred to plastic cups containing $700 \mathrm{~mL}$ of the described substrates, maintaining the information about their origin. The following characteristics were then evaluated at 90 and 180 days after sowing (DAS) in three samples per replicate of each treatment: shoot height $(\mathrm{H})$, main root length (RL), stem diameter (SD) by digital caliper, and leaf area (LA) using a leaf area integrator (AM 300) in $\mathrm{cm}^{2}$.

Next, four samples per treatment were separated in roots and shoots at 180 DAS to obtain the dry mass. The material was packed in brown paper envelopes and placed for drying in a forced circulation oven at $70{ }^{\circ} \mathrm{C}$ for 72 hours. The shoot dry mass (SDM), root dry mass (RDM) and total dry mass (TDM) were obtained by means of an analytical scale and the results expressed in grams (g). The Dickson quality index (DQI) was also determined (Dickson et al., 1960), where DQI = TDM/ $(\mathrm{HDR}+\mathrm{SDM} / \mathrm{RDM}), \mathrm{HDR}=$ shoot height $(\mathrm{H})$ to stem diameter $(\mathrm{D})$ ratio $(\mathrm{R})$ of the seedlings.

Table 1. Mean values of the substrate physical properties.

\begin{tabular}{|c|c|c|c|c|c|c|c|}
\hline Treatment & $\begin{array}{l}\text { WD } \\
\left(g / L^{1}\right)\end{array}$ & $\begin{array}{l}\text { TP } \\
(\%)\end{array}$ & $\begin{array}{l}\text { AS } \\
(\%)\end{array}$ & $\begin{array}{c}\text { RAW } \\
(\%)\end{array}$ & $\begin{array}{c}\text { WHC } 50 \mathrm{~cm} \\
(\%)\end{array}$ & $\begin{array}{c}\text { EC } \\
\left(\mathbf{d S} / \mathbf{m}^{-1}\right)\end{array}$ & $\mathrm{pH}$ \\
\hline $\mathrm{T} 1$ & 555 & 80 & 24 & 22 & 34 & 1.51 & 4.62 \\
\hline $\mathrm{T} 2$ & 519 & 80 & 22 & 23 & 35 & 1.28 & 6.08 \\
\hline T3 & 461 & 78 & 21 & 19 & 38 & 0.97 & 4.56 \\
\hline T4 & 384 & 70 & 20 & 13 & 37 & 0.48 & 4.73 \\
\hline T5 & 480 & 81 & 26 & 27 & 28 & 0.85 & 4.49 \\
\hline T6 & 394 & 77 & 25 & 30 & 22 & 1.12 & 4.53 \\
\hline T7 & 331 & 69 & 25 & 27 & 17 & 0.66 & 4.45 \\
\hline
\end{tabular}

WD: wet density; TP: total porosity; AS: aeration space; RAW: readily available water; WHC: water holding capacity, and chemicals; EC: electrical conductivity; T1: $100 \%$

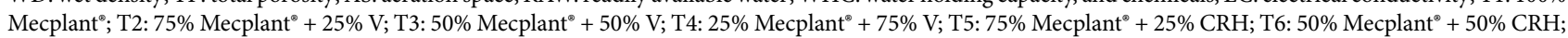
T7: $25 \%$ Mecplant $^{\oplus}+75 \% \mathrm{CRH}$

Source: LASPP, 2016. 
Chlorophyll $a, b$, total chlorophyll, and carotenoid contents were obtained at the end of the experiment (180 DAS), using four leaf samples from the central third of the shoot of four seedlings from each substrate composition. Plant material was macerated in $80 \%$ acetone and quantification of chlorophyll $a, b$, total chlorophyll, and carotenoids ( $\mathrm{mg} \mathrm{g}^{-1}$ fresh mass) was obtained by spectrophotometry at 663,645 , and $480 \mathrm{~nm}$, according to the methodology of Arnon (1949).

Results were submitted to analysis of variance, and the means were compared by the Scott-Knott test at a $5 \%$ probability of error using the Sisvar 5.6 application (Ferreira, 2008).

\section{RESULTS AND DISCUSSION}

There was a significant effect of the different substrate compositions in the emergence and ESI of cobrina seedlings (Figure 1). Figure la shows that the highest emergence percentages occurred in the treatments containing Mecplant ${ }^{\circ}$ associated with vermiculite or charcoal rice husk (T2 to T7), differing significantly from the treatment containing only commercial Mecplant $^{\oplus}$ (T1). The substrates formulated with Mecplant ${ }^{\circ}$ and vermiculite (T2, T3, and T4) had a higher ESI, stabilizing emergence at up to 69 DAS (Figure 1b), statistically differing from the other treatments where the isolated Mecplant ${ }^{\circ}$ (T1) promoted emergence stabilization at 96 DAS, while emergence stabilization for the treatments with Mecplant ${ }^{\circledR}$ associated with charcoal rice husk (T5 to T7) occurred at up to 86 DAS.

In general, isolated substrates do not satisfy all the conditions necessary for seed germination and seedling emergence and thus do not guarantee the satisfactory growth of forest species (Caldeira et al., 2008; Martins et al., 2009). Thus, according to the authors, using a mixture of substrates which favors germination, and which requires hydration and aeration of the seeds for the enzymatic reactions, as well as the emergence of the seedlings is advisable.

Vermiculite has been commonly used in the combination of substrates for producing seedlings of forest species due to characteristics such as uniformity in chemical composition, grain size, porosity, water holding capacity, and low density, providing greater ease and consequently higher emergence speed of seedlings (Martins et al., 2009). This corroborates the results observed in the present study, where the addition of vermiculite to the commercial Mecplant ${ }^{\circ}$ substrate stimulated the emergence and germination speed of cobrina seeds (Figure 1).

Although the charcoal rice husk increased the emergence percentage in relation to the control (Figure 1), ESI averages in substrates with their addition to Mecplant ${ }^{\oplus}$ were lower, i.e. there was a need of 17 more days for emergence stabilization in relation to the averages observed in substrates with addition of vermiculite, demonstrating a significant difference between them.

Charcoal rice husk can be used as a substrate mixed with other materials, since CRH presents low density and high aeration space, providing the substrate with good oxygenation, fast and efficient drainage, improving the physical properties of the final substrate. In addition, it is resistant to decomposition, free from weeds and pathogens (Saidelles et al., 2009).
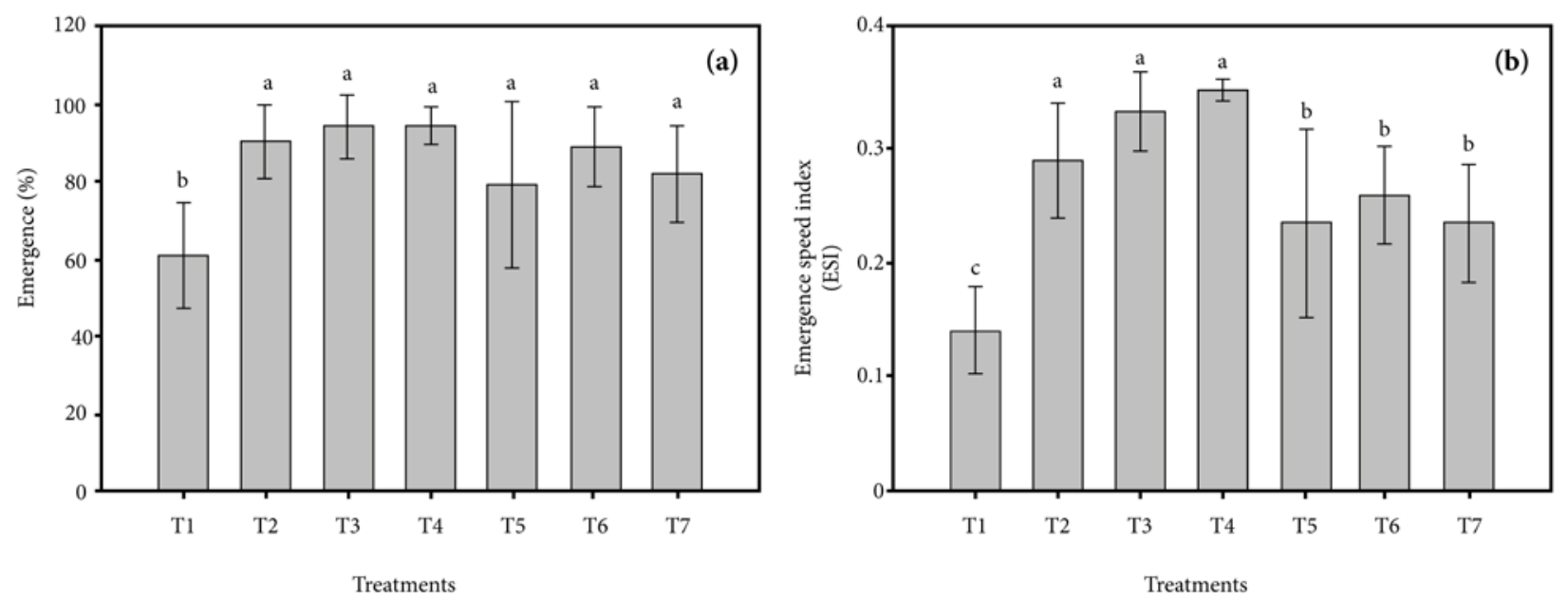

Figure 1. Emergence percentage (a) and emergence speed index (b) of cobrina seedlings (Tabernaemontana catharinensis) on different substrates at 80 DAS (days after sowing).

Means followed by the same letter do not differ one from another by the Scott-Knott test at 5\% probability. T1: 100\% Mecplant ${ }^{\oplus}$ T2: 75\% Mecplant ${ }^{\varpi}+25 \%$ V; T3:

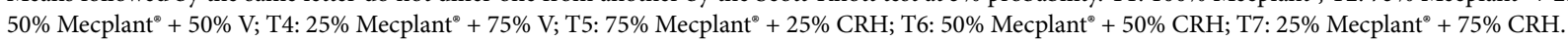


However, a good substrate should provide efficiency, emergence speed, and seedling growth, since the longer the seed and the seedling remain in the early development stages, the greater their exposure to adverse environmental conditions. The slow emergence observed in T1, T5, T6, and T7 treatments may be related to the high density of the Mecplant ${ }^{\circ}$ substrate and the low water holding capacity of these substrates combined according to their physical characteristics (Table 1), interfering with the water supply during the imbibition stage, where the seed tissues do not tolerate desiccation (Guedes et al., 2010).

Results for height, stem diameter, length of the largest root, and leaf area of cobrina seedlings are presented in Table 2. The height and leaf area were higher in the T3 and T4 treatments at 90 and 180 DAS compared to the other treatments. T2, $\mathrm{T} 3, \mathrm{~T} 4$, and $\mathrm{T} 5$ treatments provided greater stem diameter and longer root length at 90 DAS. On the other hand, there was no significant difference between treatments at 180 DAS for length of the largest root, while the T3 and T4 treatments provided a larger stem diameter.

Although vermiculite is an inert material, some of its characteristics such as greater water holding capacity (Table 1) coupled with using a fertilization source such as Osmocote ${ }^{\circledR}$ can provide higher quality in the produced seedlings, as observed in the T3 and T4 treatments that presented greater leaf area at 90 and 180 DAS (Table 2). Leaf area directly correlates with the useful photosynthetic surface area, maximizing light energy uptake and conversion to chemical energy, growth rates, leaf thickness, and assimilated partition for the other structural parts (Barbosa et al., 2013).

Additionally, as vermiculite addition increased in the substrate formulation ( $\mathrm{T} 3$ and T4), cobrina seedlings at 180 DAS expressed higher values in height ( 21.75 and $22.75 \mathrm{~cm}$, respectively) and stem diameter ( 4.25 and $4.31 \mathrm{~mm}$, respectively), statistically differing from the other formulations. According to Souza et al. (2006), height and stem diameter are fundamental in evaluating the potential of survival and growth in the postplanting of seedlings of forest species, since the larger diameter plants within the same species present greater survival due to their capacity to train and grow new roots.

However, Saidelles et al. (2009) point out that a desirable height for seedlings to be taken to field for planting should be between 30 and $35 \mathrm{~cm}$ when analyzing the variable for two native forest species in the state of Rio Grande do Sul. At the end of the experiment in the greenhouse (180 DAS), the cobrina seedlings did not reach this standard probably because the species under study needed more time in the protected environment to reach the ideal values for the variable.

For the largest root length (RL), we observed that the significant difference demonstrated between treatments at 90 DAS does not remain at 180 DAS (Table 2). This possibly occurred due to the restriction in the substrate's exploitable volume of the recipient, interrupting deep expansion of the primary root and hence the root system. An in-depth root system enables the plant to withstand periods of water deficit, developing productive potential and the ability to adapt to adverse environmental conditions and to the absorption and utilization of nutrients (Behling et al., 2014).

At 180 DAS, the shoot $(2.19 \mathrm{~g})$ and root dry mass $(1.71 \mathrm{~g})$ of plants cultivated on isolated Mecplant ${ }^{\circ}$ substrate were significantly lower than the values verified in the other compositions, and consequently total dry mass ( $3.90 \mathrm{~g}$ ) (Table 3). These parameters were higher in seedlings grown on the Mecplant ${ }^{\circ}$ and vermiculite substrates in the proportions of 50 and $50 \%$ (T3) and 25 and 75\% (T4), respectively, differing from the other treatments.

Table 2. Height, stem diameter, length of the longest root and leaf area of cobrina seedlings (Tabernaemontana catharinensis) evaluated at 90 and 180 days after sowing, grown on different substrates.

\begin{tabular}{|c|c|c|c|c|c|c|c|c|}
\hline \multirow[b]{2}{*}{ Treatment } & \multicolumn{4}{|c|}{90 DAS } & \multicolumn{4}{|c|}{180 DAS } \\
\hline & $\begin{array}{c}\mathbf{H} \\
(\mathbf{c m})\end{array}$ & $\begin{array}{c}\text { SD } \\
(\mathrm{mm})\end{array}$ & $\begin{array}{c}\mathrm{RL} \\
(\mathrm{cm})\end{array}$ & $\underset{\left(\mathbf{c m}^{2}\right)}{\mathbf{L A}}$ & $\begin{array}{c}\mathbf{H} \\
(\mathrm{cm})\end{array}$ & $\begin{array}{c}\text { SD } \\
(\mathbf{m m})\end{array}$ & $\begin{array}{c}\mathrm{RL} \\
(\mathbf{c m})\end{array}$ & $\underset{\left(\mathbf{c m}^{2}\right)}{\mathbf{L A}}$ \\
\hline T1 & $2.79 c$ & $1.56 \mathrm{~b}$ & $6.61 \mathrm{~b}$ & $8.8 \mathrm{~b}$ & $12.13 \mathrm{c}$ & $2.75 \mathrm{c}$ & $19.8 \mathrm{a}$ & $132.0 \mathrm{c}$ \\
\hline $\mathrm{T} 2$ & $3.83 \mathrm{~b}$ & $1.82 \mathrm{a}$ & $10.25 \mathrm{a}$ & $28.0 \mathrm{~b}$ & $16.60 \mathrm{~b}$ & 3. $53 \mathrm{~b}$ & $18.3 \mathrm{a}$ & $181.3 \mathrm{c}$ \\
\hline T3 & $4.94 \mathrm{a}$ & $2.03 \mathrm{a}$ & $9.41 \mathrm{a}$ & $41.0 \mathrm{a}$ & $21.75 \mathrm{a}$ & $4.25 \mathrm{a}$ & $21.5 \mathrm{a}$ & $325.3 \mathrm{a}$ \\
\hline $\mathrm{T} 4$ & $5.13 \mathrm{a}$ & $1.97 \mathrm{a}$ & $10.14 \mathrm{a}$ & $43.3 \mathrm{a}$ & $22.75 \mathrm{a}$ & $4.31 \mathrm{a}$ & $26.0 \mathrm{a}$ & $380.5 \mathrm{a}$ \\
\hline T5 & $3.66 \mathrm{~b}$ & $1.82 \mathrm{a}$ & $9.53 \mathrm{a}$ & $19.7 \mathrm{~b}$ & $17.38 \mathrm{~b}$ & $3.65 \mathrm{~b}$ & $21.3 \mathrm{a}$ & $239.6 \mathrm{~b}$ \\
\hline T6 & $3.86 \mathrm{~b}$ & $1.56 \mathrm{~b}$ & $7.34 \mathrm{~b}$ & $19.1 \mathrm{~b}$ & $17.38 \mathrm{~b}$ & $3.38 \mathrm{~b}$ & $19.8 \mathrm{a}$ & $254.6 \mathrm{~b}$ \\
\hline $\mathrm{T} 7$ & $3.81 \mathrm{~b}$ & $1.62 \mathrm{~b}$ & $6.43 \mathrm{~b}$ & $22.6 \mathrm{~b}$ & $16.25 \mathrm{~b}$ & $3.41 \mathrm{~b}$ & $20.1 \mathrm{a}$ & $198.3 \mathrm{c}$ \\
\hline
\end{tabular}

Means followed by the same letter in the column do not differ from each other by the Scott-Knott test at 5\% probability. H: height; SD: stem diameter; RL: length of the longest root; LA: leaf area; DAS: days after sowing; T1: $100 \%$ Mecplant $^{\circ}$; T2: 75\% Mecplant ${ }^{\circ}+25 \%$ V; T3: 50\% Mecplant ${ }^{\circ}+50 \%$ V; T4: $25 \%$ Mecplant ${ }^{\circ}+75 \%$ V; T5: 75\% Mecplant $^{\circ}+25 \%$ CRH; T6: 50\% Mecplant $^{\circ}+50 \%$ CRH; T7: 25\% Mecplant $^{\circ}+75 \%$ CRH. 
Low total biomass investment in seedlings grown on the exclusive composition substrate with Mecplant ${ }^{\circledR}$ resulted in a slow growth process of plants at height and leaf expansion. According to Marana et al. (2008), this indicates that the seedlings did not have good root and shoot development. Shoot dry mass indicates the rusticity of the plant and is also directly correlated with the survival and initial performance of the seedlings after planting (Gomes \& Paiva, 2004). Greater SDM can be a temporary reservoir of assimilates, because these compounds can be translocated and allocated to leaf formation when being allocated in the stem, thereby enabling greater area of radiant energy capture and contributing to increase the total dry mass (Marenco \& Lopes, 2005).

According to Table 3, the data obtained for the root system dry mass (RDM) followed the same statistical trend of the SDM, with the highest values in $\mathrm{T} 3$ and T4 treatments, while significantly decreasing in the others. According to Lima et al. (2008), a lower contribution by the root system can affect the seedlings' adaptation in definitive place, as it makes it difficult to absorb water, minerals, and to support the seedlings in the soil. A more developed root system, as observed in T3 and T4 treatments, with higher absorption surfaces and efficiency in acquiring water and nutrients is relevant, since it may partially determine the competitive ability of the produced seedling (Oliveira et al., 2008).

Although there were significant differences between the shoot and root dry masses in the implemented substrate compositions, the RDM/SDM ratio showed no difference between them, ranging from 0.74 to 0.79 (Table 3). According to Saidelles et al. (2009), the RDM and SDM values should be similar to supply the shoot's demand for water and minerals. When working with different substrate compositions in the production of Pacara Earpod Tree (timbaúva) (Enterolobium contortisiliquum) seedlings, Afonso et al. (2012) observed that this ratio was maintained at $1: 1$, showing that the shoot should be equivalent to the root.

The highest averages for the Dickson quality index (DQI) were observed in T4, T3, and T5 treatments $(0.88,0.86$, 0.81 , respectively), not differing from each other (Table 3 ). According to Fonseca et al. (2002), this index is indicated as an indicator of the seedlings' quality, considering the robustness and the phytomass distribution balance of the seedlings for its calculation. Thus, the higher the DQI, the better the quality of the produced seedling (Caldeira et al., 2012). This infers that the T. catharinensis seedlings produced on $\mathrm{T} 4, \mathrm{~T} 3$, and $\mathrm{T} 5$ substrates (Table 3 ) are considered good quality seedlings as a function of DQI. Additionally, some papers emphasizing DQI show that the Dickson quality index may vary depending on the species, the seedling management in the nursery, the type and proportion of the substrate, the container volume, and mainly according to the age at which the seedling was evaluated (Caldeira et al., 2008; Saidelles et al., 2009; Trazzi et al., 2013).

One of the most important factors for the growth and adaptation of plants to different environments is the chlorophyll content (Siebeneichler et al., 2008). For Rong-hua et al. (2006), analyzing the photosynthetic pigments is an important tool to evaluate the health and integrity of the internal apparatus of the cell during the photosynthesis process. According to Gomes et al. (2008), substrates can indirectly interfere in pigment production and consequently the photosynthetic efficiency due to the availability of nutrients and water to the plant. However, substrate compositions in our study did not significantly interfere in the contents of the chlorophyll $a, b$, and total chlorophyll pigments in cobrina leaves at 180 DAS (Table 4).

Table 3. Shoot dry mass, root dry mass, total dry mass, root and shoot dry mass ratio, and Dickson quality index of cobrina seedlings (Tabernaemontana catharinensis) grown on different substrates 180 days after seeding.

\begin{tabular}{cccccc} 
Treatment & SDM (g) & RDM (g) & TDM (g) & RDM/SDM & DQI \\
\hline T1 & $2.19 \mathrm{c}$ & $1.71 \mathrm{c}$ & $3.90 \mathrm{c}$ & $0.79 \mathrm{a}$ & $0.69 \mathrm{~b}$ \\
T2 & $2.51 \mathrm{~b}$ & $1.97 \mathrm{~b}$ & $4.47 \mathrm{~b}$ & $0.79 \mathrm{a}$ & $0.75 \mathrm{~b}$ \\
T3 & $3.22 \mathrm{a}$ & $2.37 \mathrm{a}$ & $5.59 \mathrm{a}$ & $0.74 \mathrm{a}$ & $0.86 \mathrm{a}$ \\
T4 & $3.35 \mathrm{a}$ & $2.47 \mathrm{a}$ & $5.81 \mathrm{a}$ & $0.74 \mathrm{a}$ & $0.88 \mathrm{a}$ \\
T5 & $2.77 \mathrm{~b}$ & $2.12 \mathrm{~b}$ & $4.89 \mathrm{~b}$ & $0.77 \mathrm{a}$ & $0.81 \mathrm{a}$ \\
T6 & $2.71 \mathrm{~b}$ & $1.99 \mathrm{~b}$ & $4.70 \mathrm{~b}$ & $0.74 \mathrm{a}$ & $0.72 \mathrm{~b}$ \\
\hline T7 & $2.62 \mathrm{~b}$ & $2.01 \mathrm{~b}$ & $4.63 \mathrm{~b}$ & $0.77 \mathrm{a}$ & $0.76 \mathrm{~b}$ \\
\hline
\end{tabular}

Means followed by the same letter in the column do not differ from each other by the Scott-Knott test at 5\% probability. SDM: shoot dry mass; RDM: root dry mass; TDM: total dry mass; RDM: root dry mass ratio; DQI: Dickson quality index; T1: 100\% Mecplant ${ }^{\circ}$; T2: 75\% Mecplant ${ }^{\circ}+25 \%$ V; T3: 50\% Mecplant ${ }^{\circ}+50 \%$ V; T4: $25 \%$ Mecplant $^{\circ}+75 \%$ V; T5: 75\% Mecplant ${ }^{\circ}+25 \%$ CRH; T6: 50\% Mecplant $^{\circ}+50 \%$ CRH; T7: 25\% Mecplant $^{\circ}+75 \%$ CRH. $^{\circ}$ 
Table 4. Mean values of chlorophyll $a, b$, total chlorophyll, and carotenoids in cobrina seedlings (Tabernaemontana catharinensis A. DC.) at 180 days after seeding, cultivated on different substrates.

\begin{tabular}{|c|c|c|c|c|}
\hline Treatment & $\begin{array}{c}\text { Chl } a \\
\left(\mathrm{mg} \mathrm{g}^{-1} \text { FM) }\right.\end{array}$ & $\begin{array}{c}\mathrm{Chl} b \\
\left(\mathrm{mg} \mathrm{g}^{-1} \mathbf{F M}\right)\end{array}$ & $\begin{array}{c}\text { Chl total } \\
\left(\mathbf{m g ~ g}^{-1} \mathbf{F M}\right)\end{array}$ & $\begin{array}{l}\text { Carotenoids } \\
\left(\mathbf{m g ~ g}^{-1} \text { FM) }\right.\end{array}$ \\
\hline $\mathrm{T} 1$ & $1.25 \mathrm{a}$ & $0.28 \mathrm{a}$ & $1.53 \mathrm{a}$ & $0.39 \mathrm{a}$ \\
\hline $\mathrm{T} 2$ & $1.15 \mathrm{a}$ & $0.24 \mathrm{a}$ & $1.38 \mathrm{a}$ & $0.33 \mathrm{a}$ \\
\hline $\mathrm{T} 3$ & $1.36 \mathrm{a}$ & $0.31 \mathrm{a}$ & $1.67 \mathrm{a}$ & $0.38 \mathrm{a}$ \\
\hline $\mathrm{T} 4$ & $1.43 \mathrm{a}$ & $0.29 \mathrm{a}$ & $1.72 \mathrm{a}$ & $0.38 \mathrm{a}$ \\
\hline T5 & $1.43 \mathrm{a}$ & $0.30 \mathrm{a}$ & $1.73 \mathrm{a}$ & $0.40 \mathrm{a}$ \\
\hline T6 & $1.45 \mathrm{a}$ & $0.33 \mathrm{a}$ & $1.78 \mathrm{a}$ & $0.40 \mathrm{a}$ \\
\hline T7 & $0.93 \mathrm{a}$ & $0.22 \mathrm{a}$ & $1.15 \mathrm{a}$ & $0.28 \mathrm{a}$ \\
\hline
\end{tabular}

Means followed by the same letter in the column do not differ from each other by the Scott-Knott test at $5 \%$ probability. Chl $a$ : chlorophyll $a$; Chl $b$ : chlorophyll $b$; Chl total: total chlorophyll; FM: fresh mass; T1: 100\% Mecplant ; T2: 75\% Mecplant ${ }^{\circ}+25 \%$ V; T3: 50\% Mecplant ${ }^{\circ}+50 \%$ V; T4: 25\% Mecplant ${ }^{\circ}+75 \%$ V; T5: 75\% Mecplant $^{\circledR}+25 \%$ CRH; T6: 50\% Mecplant $^{\circ}+50 \%$ CRH; T7: 25\% Mecplant $^{\circledR}+75 \%$ CRH.

Still in Table 4, the values obtained for the carotenoid content did not differ significantly between the studied substrates. Carotenoids during the photosynthesis process can perform two distinct functions: light absorption in the light capture complexes acting as accessory pigments, and photoprotective action of the photochemical apparatus, predicting photooxidative damage to the chlorophyll molecules (Raven et al., 2007).

Although there were no differences between the contents of the photosynthetic pigments in the leaves of cobrina plants cultivated in the different substrate formulations, there was influence in the leaf area values (Table 2), with these values increasing in the Mecplant ${ }^{\bullet}$ substrates combined with vermiculite in the proportions of 50 and $75 \%$, which probably resulted in higher photosynthetic efficiency and higher dry mass production (Table 3 ) in these treatments, and greater efficiency in using available water and nutrients can also be inferred in these combinations.

\section{CONCLUSIONS}

Substrates formulated with $50 \%$ Mecplant $^{\oplus}+50 \%$ Vermiculite and $25 \%$ Mecplant $^{\circ}+75 \%$ Vermiculite provide greater expression of seed vigor, higher seedling emergence speed, and greater growth and development of the seeds, proving to be more suitable for forming cobrina seedlings among the studied substrates.

Isolated use of commercial Mecplant ${ }^{\oplus}$ substrate provides a lower emergence percentage and emergence speed of produced cobrina seedlings and negatively affects the morphophysiological parameters.
Substrates used alone or in combination did not significantly influence the photosynthetic pigment contents.

\section{ACKNOWLEDGEMENTS}

The authors thank the Universidade Federal de Santa Maria (UFSM).

\section{SUBMISSION STATUS}

Received: 14 July 2017

Accepted: 28 Sept. 2018

Associate editor: João Latorraca

(D) 0000-0002-5969-5199

\section{CORRESPONDENCE TO}

Marcelo Vielmo Afonso

Instituto Federal de Educação, Ciência e Tecnologia Farroupilha (IFFAR), Rua Erechim, 860, CEP 98280-000, Panambi, RS, Brasil e-mail: marcelovielmo@yahoo.com.br

\section{FINANCIAL SUPPORT}

Universidade Federal de Santa Maria (UFSM).

\section{REFERENCES}

Afonso MV, Martinazzo EG, Aumonde TZ, Villela FA. Composição do substrato, vigor e parâmetros fisiológicos de mudas de timbaúva (Enterolobium contortisiliquum (vell.) morong). Revista Árvore 2012; 36(6): 1019-1026. 10.1590/S0100-67622012000600003

Arnon DI. Copper enzymes in isolated chloroplasts: polyphenoloxidases in Beta vulgaris. Plant Physiology 1949; 24(1): 1-15. 10.1104/pp.24.1.1

Barbosa ML, Silva TGF, Silva AC, Lima ALA, Souza CAA, Almeida MG. Crescimento inicial de espécies ocorrentes no semiárido brasileiro: 
biomassa, biometria e análise morfogênica. Revista Brasileira de Geografia Física 2013; 6(3): 522-539. 10.26848/rbgf.v6.3.p522-539

Basso VM, Jacovine LAG, Alves RR, Vieira SLP. Influência da certificação florestal no cumprimento da legislação ambiental e trabalhista na região amazônica. Acta Amazônica 2011; 41(1): 69-76. 10.1590/S004459672011000100008

Behling M, Neves JCL, Barros NF, Kishimoto CB, Smit L. Eficiência de utilização de nutrientes para formação de raízes finas e médias em povoamento de teca. Revista Árvore 2014; 38(5): 837-846. 10.1590/ S0100-67622014000500008

Bélo M, Barbosa JC, Braganholi DF, Pereira PS, Bertoni BW, Zingaretti SM, Beleboni RO. Avaliação do efeito bioinseticida dos extratos de Tabernaemontana catharinensis A.DC. (Apocynaceae) e Zeyheria montana Mart. (Bignoniaceae) sobre a mosca Zaprionus indianus (Díptera: Drosophilidae) (Gupta, 1970). Revista Brasileira de Biociências 2009; 7(3): 235-239.

Caldeira MVW, Delarmelina WM, Lübe SG, Gomes DR, Gonçalves EO, Alves AF. Biossólido na composição de substrato para a produção de mudas de Tectona grandis. Floresta 2012; 42(1): 77-84. 10.5380/ rf.v42i1.26302

Corrêa AG, Vieira PC, editors. Produtos naturais no controle de insetos. São Carlos: EdUFSCar; 2001.

Caldeira MVW, Rosa GN, Fenilli TAB, Harbs RMP. Composto orgânico na produção de mudas de aroeira-vermelha. Scientia Agraria 2008; 9(1): 27-33. 10.5380/rsa.v9i1.9898

Dickson A, Leaf AL, Hosner JF. Quality appraisal of white spruce and white pine seedling stock in nurseries. Forest Chronicle 1960; 36(1): 10-13. $10.5558 / \mathrm{tfc} 36010-1$

Erismann NM, Machado EC, Godoy IJ. Capacidade fotossintética de genótipos de amendoim em ambiente natural e controlado. Pesquisa Agropecuária Brasileira 2006; 41(7): 1099-1108. 10.1590/S0100204X2006000700005

Ferreira DF. Sisvar: um programa para análises estatísticas e ensino de estatística. Revista Symposium 2008; 6(2): 36-41.

Fonseca EP, Valéri SV, Miglioranza E, Fonseca NAN, Couto L. Padrão de qualidade de mudas de Trema micrantha (L.) Blume, produzidas sob diferentes períodos de sombreamento. Revista Árvore 2002; 26(4): 515-523. 10.1590/S0100-67622002000400015

Gomes DR, Caldeira MVW, Delarmelina WM, Gonçalves EO, Trazzi PA. Lodo de esgoto como substrato para a produção de mudas de Tectona grandis L. Cerne 2013; 19(1): 123-131. 10.1590/S010477602013000100015

Gomes IAC, Castro EM, Soares AM, Alves JD, Alvarenga MIN, Alves E et al. Alterações morfofisiológicas em folhas de Coffea arabica L. cv. Oeiras sob influência do sombreamento por Acacia mangium Willd. Ciência Rural 2008; 38(1): 109-115. 10.1590/S0103-84782008000100018

Gomes JM, Paiva HN. Viveiros florestais: propagação sexuada. 3rd ed. Viçosa: Editora UFV; 2004.

Guedes RS, Alves EU, Gonçalves EP, Viana JS, Moura MF, Costa EG. Emergência e vigor de plântulas de Amburana cearensis (Allemão) A.C. Smith em função da posição e da profundidade de semeadura. Semina: Ciências Agrárias 2010; 31(4): 843-850. 10.5433/1679-0359.2010v31n4p843

Labouriau LG, Valadares MEB. On the germination of seeds Calotropis procera (Ait.) Ait.f. Anais da Academia Brasileira de Ciências 1976; 48(2): 263-284.
Lima JD, Silva BMS, Moraes WS, Dantas VAV, Almeida CC. Efeitos da luminosidade no crescimento de mudas de Caesalpinia ferrea Mart. ex Tul. (Leguminosae, Caesalpinoideae). Acta Amazonica 2008; 38(1): 5-10. 10.1590/S0044-59672008000100002

Lorenzi H. Árvores brasileiras: manual de identificação e cultivo de plantas arbóreas nativas do Brasil. Nova Odessa: Instituto Plantarum; 2009.

Maguire JD. Speed of germination-aid in selection and evaluation for seedling emergence and vigor. Crop Science 1962; 2(2): 176-177. 10.2135/cropsci1962.0011183X000200020033x

Marana JP, Miglioranza E, Fonseca EP, Kainuma RH. Índices de qualidade e crescimento de mudas de café produzidas em tubetes. Ciência Rural 2008; 38(1):39-45. 10.1590/S0103-84782008000100007

Marenco RA, Lopes NF. Fisiologia vegetal: fotossíntese, respiração, relações hídricas e nutrição mineral. 2nd ed. Viçosa: Editora UFV; 2005.

Martins CC, Bovi MLA, Spiering SH. Umedecimento do substrato na emergência e vigor de plântulas de pupunheira. Revista Brasileira de Fruticultura 2009; 31(1):224-230. 10.1590/S0100-29452009000100031

Mesquita EF, Chaves LHG, Freitas BV, Silva GA, Sousa MVR, Andrade R. Produção de mudas de mamoeiro em função de substratos contendo esterco bovino e volumes de recipientes. Revista Brasileira de Ciências Agrárias 2012; 7(1): 58-65. 10.5039/agraria.v7ila1448

Oliveira RB, Lima JSS, Souza CAM, Silva AS, Martins Filho S. Produção de mudas de essências florestais em diferentes substratos e acompanhamento do desenvolvimento em campo. Ciência e Agrotecnologia 2008; 32(1): 122-128. 10.1590/S1413-70542008000100018

Piana M, Boligon AA, Brum TF, Zadra M, Belke BV, Froeder ALF et al. Phytochemical analysis and antioxidant capacity of Tabernaemontana catharinensis A. DC. fruits and branches. Anais da Academia Brasileira de Ciências 2014; 86(2): 881-888. 10.1590/0001-3765201420120020

Raven PH, Evert RF, Eichhorn SE. Biologia vegetal. 7th ed. São Paulo: Guanabara Koogan; 2007.

Rong-hua L, Pei-guo G, Baumz M, Grando S, Ceccarelli S. Evaluation of chlorophyll content and fluorescence parameters as indicators of drought tolerance in barley. Agricultural Sciences in China 2006; 5(10): 551-557. 10.1016/S1671-2927(06)60120-X

Saidelles FLF, Caldeira MVW, Schirmer WN, Sperandio HV. Casca de arroz carbonizada como substrato para produção de mudas de tamboril-da-mata e garapeira. Semina: Ciências Agrárias 2009; 30(4 Suppl 1): 1173-1186. 10.5433/1679-0359.2009v30n4Sup1p1173

Siebeneichler SC, Freitas GA, Silva RR, Adorian GC, Capellari D. Características morfofisiológicas em plantas de Tabebuia heptaphyilla (vell.) tol. em condições de luminosidade. Acta Amazonica 2008; 38(3): 467-472. 10.1590/S0044-59672008000300011

Souza CAM, Oliveira RB, Martins Filho S, Lima JSS. Crescimento em campo de espécies florestais em diferentes condições de adubação. Ciência Florestal 2006; 16(3): 243-249. 10.5902/198050981905

Trazzi PA, Caldeira MVW, Passos RR, Gonçalves EO. Substratos de origem orgânica para produção de mudas de teca (Tectona grandis Linn. F.). Ciência Florestal 2013; 23(3): 401-409. 10.5902/1980509810551

Wendling I, Guastala D, Dedecek R. Características físicas e químicas de substratos para produção de mudas de Ilex paraguariensis St. Hil. Revista Árvore 2007; 31(2): 209-220. 10.1590/S010067622007000200003 